\title{
Ocena skuteczności leczenia i czynników prognostycznych ze szczególnym uwzględnieniem receptorów steroidowych i HER2 u chorych na wczesnego raka piersi
}

\author{
Jacek Gałecki' , Marta Olszyna-Serementa ${ }^{1}$, Anna Majstrak², \\ Katarzyna Wiśniowska ${ }^{1}$, Mateusz Spałek ${ }^{1}$, Wojciech Michalski ${ }^{3}$
}

Wstęp. Dobór leczenia uzupełniającego chorych na wczesnego raka piersi po operacji oszczędzającej zależy od wielu czynników prognostycznych, a szczególnie od układu receptorów steroidowych (URS) i HER2.

Celem pracy jest ocena skuteczności leczenia chorych poprzez zbadanie przeżycia bezobjawowego (PB) i ryzyka nawrotu lokoregionalnego raka piersi, jak również analiza wpływu klasycznych czynników prognostycznych z uwzględnieniem URS i HER2 na PB chorych przed erą leczenia trastuzumabem.

Materiał i metoda. Badaniem objęto kolejnych 615 kobiet chorych na wczesnego inwazyjnego raka piersi leczonych metodą oszczędzającą w Centrum Onkologii w Warszawie w latach 2003-2006. U 40\% chorych stosowano uzupełniającą chemioterapię drugiej i trzeciej generacji, a u 28\% hormonoterapię. Po operacji i zakończeniu chemioterapii stosowano radioterapię piersi metodą hipofrakcjonacji dawki w czasie 3-4 tygodni. W badaniu uwzględniono następujące czynniki prognostyczne: wiek chorych, stan hormonalny, strona leczonej piersi, pT, pN, typ histopatologiczny raka, G, obecność komponentu raka przedinwazyjnego w raku inwazyjnym, rozmiar marginesów wokół usuniętego guza i 4 podtypy raka piersi różniące się URS i HER2 - luminalny (ER dodatni i/lub PGR dodatni) HER2 ujemny, luminalny (ER dodatni i/lub PGR dodatni) HER2 dodatni, trójujemny i nieluminalny (ER ujemny i/lub PGR ujemny) HER2 dodatni. W analizie statystycznej krzywe przeżycia obliczano metoda Kaplana-Meiera, do oceny ryzyka nawrotu wykorzystano metodę konkurujących ryzyk, a czynniki prognostyczne badano w modelu proporcjonalnego ryzyka Coxa. Mediana obserwacji wynosiła 8 lat.

Wyniki. Prawdopodobieństwo 8-letniego przeżycia bezobjawowego i ryzyko nawrotu lokoregionalnego wyniosły odpowiednio: $89 \% ; 4,6 \%$. Potwierdzono negatywny wpływ na ryzyko niepowodzenia w leczeniu raka piersi dla następujących czynników prognostycznych: młodego wieku, liczby zajętych przez przerzuty węzłów chłonnych (powyżej trzech) i niskiego stopnia zróżnicowania raka (G3). Nie stwierdzono istotnego statystycznie wpływu podtypów biologicznych na skuteczność leczenia ani w analizie jednoczynnikowej, ani wieloczynnikowej — test log-rank $p=0,19$. Wykazano jednakże występowanie ujemnego trendu prawdopodobieństwa przeżycia bez niepowodzenia dla podtypów biologicznych w następującym porządku: luminalny HER2 (ujemny), luminalny HER2 (dodatni), trójujemny i nieluminalny HER2 (dodatni) - test log-rank dla trendu $p=0,03$ ). Analiza rozkładu badanych czynników prognostycznych potwierdziła, że u chorych w podtypie biologicznym trójujemnym i neluminalnym HER2 (dodatnim) znamiennie częściej niż w typach luminalnym HER2 (ujemnym) i luminalnym HER2 (dodatnim), stwierdza się młodsze chore, z większym guzem, i większą niż 3 liczbą węzłów chłonnych z przerzutami w jamie pachowej i z częstszym rozpoznawanym rakiem niskozróżnicowanym $\mathrm{G} 3$.

Wnioski. 1. Wysokie prawdopodobieństwo 8-letniego przeżycia bezobjawowego chorych i niskie ryzyko nawrotu lokoregionalnego raka piersi upoważnia do pozytywnej oceny leczenia oszczędzającego w Centrum Onkologii w latach

\footnotetext{
${ }^{1}$ Zakład Teleradioterapii II

${ }^{2}$ Klinika Nowotworów Piersi i Chirurgii Rekonstrukcyjnej

${ }^{3}$ Biuro Badań Klinicznych i Biostatystyki

Centrum Onkologii — Instytut im. Marii Skłodowskiej-Curie w Warszawie
} 
2003-2006. 2. Pomimo agresywnego leczenia nadal najsilniejszymi czynnikami prognostycznymi pozostają: młody wiek chorych, liczba zajętych przez przerzuty węzłów chłonnych w pasze (powyżej trzech) i niskie zróżnicowanie raka (G3). 3. Gorsze rokowanie chorych z rozpoznanym podtypem raka piersi nieluminalnym HER2 (dodatnim), uzasadnia wprowadzenie leczenia celowanego molekularnie, nakierowanego na receptor HER2.

\section{Evaluation of early breast cancer treatment effects and prognostic factors with special reference to steroid and HER2 receptors}

Introduction. Choice of adjuvant systemic therapy in early breast cancer patients followed breast conserving surgery depends on many prognostic factors especially from steroid (estrogen receptor — ER; progesterone receptor — PR) and HER-2 receptor status.

Purpose. To evaluate the treatment we determined disease free survival (DFS) and the risk of local recurrence and examined the influence of classical prognostic factors with special consideration of the biological subtype of breast cancer on DFS before the era of trastuzumab treatment.

Patients and methods. Consecutively 615 female patients with early invasive breast cancer received breast conservative treatment between 2003 and 2006 in the Oncological Center in Warsaw. Data were prospectively collected. Adjuvant systemic therapy of second and third generation in $40 \%$ of patients had been given and in $28 \%$ of patients hormonotherapy was applied. After surgery and chemotherapy, irradiation with mild hypofractionation during 3 or 4 weeks was used. The following prognostic factors were included in the study: age, menopausal status, breast laterality, pT, pN, histology, grade, EIC, margins, and four biological subtypes: Luminal (ER positive and/or PR positive) HER-2 negative, Luminal (ER positive and/or PR positive) HER-2 positive, Triple-Negative, Non-Luminal (ER positive and/or PR positive) HER-2 positive. Survival curves were obtained using the Kaplan Maier method. To analyse time to recurrence, the competing risk method was performed. To study the influence of prognostic factors on DFS the proportional hazards model of Cox was used. The median follow-up time was 8 years.

Results. The 8-year DFS and cumulative loco-regional recurrence (CLRR) rate were $89 \%$ and $4.6 \%$ respectively. The significant factors influencing DFS were: young age of patients, number of involved nodes above three and grade 3 histological malignancy. Biological subtypes of breast cancer were not significant predictors for DFS in the univariate or multivariate analysis - logrank test: $p=0.19$. It was shown, however, the probability of occurrence of the negative trend DFS for biological subtypes in the following order: Luminal HER2 (negative), Luminal HER2 (positive), Triple-negative and Nonluminal HER2 (positive) - logrank test for trend: $p=0.03$. The analysis examined the distribution of prognostic factors and confirmed that in biological subtype Triple-negative and Nonluminal HER2 (positive) significantly more often than in the types of Luminal HER2 (negative) and Luminal HER2 (positive), were younger patients, with larger tumour, with more than 3 involved nodes and grade 3 histological malignancy.

Conclusions. 1. High probability of 8-year DFS and low CLRR rate of breast cancer indicated a positive assessment of conserving therapy at the Cancer Center in Warsaw between 2003-2006. 2. Despite aggressive treatment the strongest prognostic factors still remain: the young age of patients, the number of involved lymph node in the axillary fossa greater than three and low differentiation of cancer G3. 3. The worst prognosis is for patients diagnosed with breast cancer in subtype Nonluminal HER2 (positive), and this justifies the introduction of molecular targeted therapies aimed at HER2.

NOWOTWORY Journal of Oncology 2015; 65, 6: 458-464

Słowa kluczowe: wczesny rak piersi, czynniki prognostyczne, receptory steroidowe i HER2

Key words: early breast cancer, prognostic factors, steroid and HER2 receptors

\section{Wstęp}

Rokowanie chorych na raka piersi zależy od wielu czynników prognostycznych, których znaczenie pomimo leczenia nie ulega zmianie. Do podstawowych czynników prognostycznych związanych z chorą należą m.in. wiek i stan menopauzalny, a związanych z rakiem - jego zaawansowanie, określane systemem TNM, typ histopatologiczny, stopień złośliwości G i obecność receptora steroidowego
ER, nadekspresja białka HER2 oraz markera proliferacyjnego Ki 67 [1-3]. Od dawna również potwierdzono w badaniach genetycznych na mikromacierzy heterogenność raka piersi. Okazało się, że geny z tkanki raka układają się w pewne grupy molekularne, którym odpowiadają podtypy biologiczne raka piersi, charakteryzujące się heterogennym fenotypem tkanki nowotworowej, różniącej się m.in.: zdolnością do proliferacji, różnicowania, a przede wszystkim układem 
receptorów steroidowych (URS), HER 2 i Ki 67. Układ tych receptorów stanowi surogat do wyróżnienia przynajmniej 4 głównych podtypów biologicznych raka piersi o różnym rokowaniu i jednocześnie stanowi obecnie najsilniejszy czynnik predykcyjny decydujący w dużym stopniu o kwalifikacji do leczenia systemowego chorych. Wprowadzenie antracyklin, taksoidów i leczenia celowanego molekularnie nakierowanego na receptor HER2 doprowadziło do znacznej poprawy wyników leczenia chorych z rozpoznaniem podtypów biologicznych nieluminalnych [4, 5].

W Centrum Onkologii w Warszawie u chorych na wczesnego raka piersi po operacji oszczędzającej w latach 2003-2006 w leczeniu uzupełniającym oprócz skróconej radioterapii stosowano schematy chemioterapii zawierające cytostatyki 2 i 3 generacji i hormonoterapię tamoksyfenem, gosereliną lub inhibitorami aromatazy. Dobór leczenia uzupełniającego chorych zależał od czynników prognostycznych, URS i HER2. Nie stosowano jeszcze rutynowo w tym okresie oznaczania receptora Ki 67 i leczenia celowanego trastuzumabem. W obecnej pracy postanowiono ocenić skuteczność takiego leczenia i zbadać wpływ klasycznych czynników prognostycznych z uwzględnieniem podtypów biologicznych na rokowanie chorych.

\section{Materiał i metody}

Badaniem objęto 615 kobiet chorych na wczesnego inwazyjnego raka piersi leczonych metodą oszczędzającą (Breast Conservative Treatment - BCT) w Centrum Onkologii - Instytucie w Warszawie na Ursynowie w latach 2003-2006. Najmłodsza chora miała 26, najstarsza 82 lata - mediana 53 lata. Rak w piersi prawej lub lewej występował z podobną częstością odpowiednio u $52 \%$ i $48 \%$ chorych — tabela I. U wszystkich 615 chorych wykonano tumorektomię, po której u 19\% chorych w trakcie drugiej operacji poszerzano marginesy. Łączna ocena mikroskopowa wielkości marginesów tkanki zdrowej od inwazyjnej komponenty raka wykazała, że u 258/615 (42\%) chorych margines wyniósł co najmniej $2 \mathrm{~mm}$. U 312/615 (52\%) chorych najmniejszy margines $1 \mathrm{~mm}$ stwierdzano od powięzi i u tych chorych marginesu nie poszerzano. U 36/615 (6\%) chorych nie uzyskano informacji o wielkości marginesów. U 30\% pacjentek guz w piersi w badaniu pooperacyjnym nie przekraczał $1 \mathrm{~cm}$, a u 79\% - 2 cm. U 298/615 (49\%) chorych diagnostykę węzłów chłonnych pachowych zakończono na procedurze węzła wartowniczego, a u 317/615 (51\%) chorych wykonano limfadenektomię trzech pięter jamy pachowej — tabela II. Dwuetapowe operacje wykonano u 35\% chorych. Przerzuty w węzłach chłonnych pachowych stwierdzono u $22 \%$ chorych, w tym jedynie u 5\% chorych liczba zajętych węzłów chłonnych przekraczała 3. Najczęściej w badaniu histopatologicznym rozpoznawano raka przewodowego, rzadziej zrazikowego i inne typy raka — odpowiednio u 56\%, 20\% i 18\% chorych. U $17 \%$ chorych rak występował w trzecim stopniu
Tabela I. Charakterystyka 615 chorych na wczesnego raka piersi po leczeniu oszczędzającym (BCT) w latach 2003-2006

\begin{tabular}{|c|c|c|}
\hline Czynniki & & n (\%) \\
\hline Wiek: & $\leq 50$ lat & $213(35)$ \\
\hline mediana 53 lata & $>50$ lat & $402(65)$ \\
\hline przedmenopauzalne & & $178(29)$ \\
\hline pomenopauzalne & & $437(71)$ \\
\hline \multicolumn{3}{|l|}{ Pierś: } \\
\hline prawa & & $318(52)$ \\
\hline lewa & & $297(48)$ \\
\hline pT1a & & $45(7)$ \\
\hline pT1b & & $141(23)$ \\
\hline pT1c & & $298(49)$ \\
\hline pT2 & & $131(21)$ \\
\hline pN0 (liczba zajętych węzłów) & & $479(78)$ \\
\hline pN1 (1-3) & & $107(17)$ \\
\hline pN2 (4-9) & & $22(4)$ \\
\hline pN3 (>9) & & $7(1)$ \\
\hline \multicolumn{3}{|l|}{ Stopnie: } \\
\hline 1 & & $403(66)$ \\
\hline IIA & & $165(27)$ \\
\hline IIB & & $47(7)$ \\
\hline \multicolumn{3}{|l|}{ Wielkość marginesów w mm: } \\
\hline 1 & & $321(52)$ \\
\hline 2 & & $142(23)$ \\
\hline 3 & & $99(16)$ \\
\hline 4 & & $17(3)$ \\
\hline nie określono & & $36(6)$ \\
\hline \multicolumn{3}{|l|}{ Typy raka inwazyjnego: } \\
\hline ductale & & $346(56)$ \\
\hline lobulare & & $125(20)$ \\
\hline inne & & $107(18)$ \\
\hline nie określono & & $37(6)$ \\
\hline \multicolumn{3}{|l|}{ Stopień złośliwości: } \\
\hline G1 & & $144(23)$ \\
\hline G2 & & $210(34)$ \\
\hline G3 & & $102(17)$ \\
\hline nie określono & & $159(26)$ \\
\hline \multicolumn{3}{|l|}{ Podtypy biologiczne: } \\
\hline Luminalny HER2 (-) & & $399(65)$ \\
\hline Luminalny HER2 (+) & & $70(11,5)$ \\
\hline Trójujemny & & $63(10)$ \\
\hline Nieluminalny HER2 (+) & & $27(4,5)$ \\
\hline nie określono & & $56(9)$ \\
\hline
\end{tabular}

złośliwości histopatologicznej-G3.Wyróżniono następujące 4 podtypy raka piersi różniące się URS i HER2 — luminalny (ER dodatni i/lub PGR dodatni) HER2 ujemny, luminalny (ER dodatni i/lub PGR dodatni) HER2 dodatni, trójujemny 
Tabela II. Metody leczenia

\begin{tabular}{|c|c|}
\hline Metody leczenia & Liczba chorych (\%) \\
\hline \multicolumn{2}{|l|}{ Chirurgia: } \\
\hline $\mathrm{Tu}+\mathrm{pw} \mathrm{w}^{1}$ & $298(49)$ \\
\hline $\mathrm{Tu}+\mathrm{LP} \mathrm{P}^{2}$ & $317(51)$ \\
\hline \multicolumn{2}{|l|}{ Radioterapia-obszar: } \\
\hline pierś & $586(95)$ \\
\hline pierś i węzły chłonne & $29(5)$ \\
\hline \multicolumn{2}{|l|}{ Dawka całkowita/czas: } \\
\hline $42,5 \mathrm{~Gy} / 3,5$ tygodni + boost & $559(91)$ \\
\hline $45 \mathrm{~Gy} / 4$ tygodnie + boost & $56(9)$ \\
\hline \multicolumn{2}{|l|}{ Leczenie systemowe uzupełniające } \\
\hline hormonoterapia ${ }^{3}$ & $175(28)$ \\
\hline chemioterapia ${ }^{4}$ & $244(40)$ \\
\hline nie stosowano & $196(32)$ \\
\hline
\end{tabular}

Tumorektomia + procedura węzła wartowniczego

${ }^{2}$ Tumorektomia + limfadenektomia trzech pięter jamy pachowe

${ }^{3}$ Hormonoterapia: tamoksyfen, goserelina, inhibitory aromatazy

${ }^{4}$ Schematy chemioterapii 2 i 3 generacji

i nieluminalny (ER ujemny i/lub PGR ujemny) HER2 dodatni. Wśród całej grupy 615 chorych typy: luminalny HER2 ujemny, luminalny HER2 dodatni, trójujemny i nieluminalny HER2 dodatni występowały odpowiednio u: 65\%, 11,5\%, 10\%, 4,5\% chorych. U 56 (9\%) chorych nie udało się ustalić podtypu biologicznego raka piersi. Większość chorych po operacji napromieniana była jedynie na obszar piersi - 95\%. Jedynie u $6 \%$ chorych napromienianie rozszerzano na obszary węzłów chłonnych nadobojczykowo-pachowych. Obszaru węzłów chłonnych przymostkowych nie napromieniano. Planowanie radioterapii odbywało się z użyciem symulatora i tomografii komputerowej w systemie 3D, zgodnie z zasadami ICRU 50 [6]. W analizowanej grupie $\mathrm{u} 615$ chorych stosowano radioterapię pooperacyjną metodą łagodnej hipofrakcjonacji dawki fotonami X $6 \mathrm{MeV}$ i $15 \mathrm{MeV}$. U 95\% chorych dawka całkowita wynosiła 42,5 Gy, podawana we frakcjach dziennych po 2,5 Gy w czasie 3,5 tygodnia, a u 9\% dawka całkowita wynosiła 45 Gy we frakcjach dziennych po 2,25 Gy w czasie 4 tygodni. U wszystkich chorych po zakończeniu radioterapii na całą pierś podwyższano dawkę na lożę po tumorektomii (tzw. boost) fotonami X planowanymi w 3D. Stosowano dawki frakcyjne od 2 Gy do 2,5 Gy i dawki całkowite od 8 Gy do 16 Gy w czasie od 4 do 10 dni. Wszystkie pola fotonowe weryfikowano $w$ trakcie radioterapii, porównując ich zgodność z zaplanowanymi. Spośród 615 chorych uzupełniające leczenie systemowe otrzymało $68 \%$ chorych: $40 \%$ chemioterapię i $28 \%$ hormonoterapię - tabela II. Radioterapię pooperacyjną rozpoczynano po zakończeniu chemioterapii i po ustąpieniu objawów toksycznych, nie wcześniej jednak niż 4 i nie później niż 8 tygodni od ostatniego podania cytostatyków. Mediana obserwacji wynosiła 96 miesięcy (8 lat) — minimum 8,3 miesiąca, maximum 129 miesięcy.

\section{Metody statystyczne}

Do opisu materiału zastosowano standardowe narzędzia statystyki opisowej: tabele częstości i tabele krzyżowe dla zmiennych kategorycznych, wartości ekstremalne, średnią i odchylenie standardowe dla zmiennych ciągłych o rozkładzie normalnym. Prawdopodobieństwo przeżycia obliczano metodą Kaplana-Meiera [7]. Czas przeżycia bezobjawowego (PB) liczono od daty tumorektomii do daty pierwszego niepowodzenia: nawrotu lokoregionalnego (samodzielnego i/lub z rozpoznanymi w czasie nie krótszym niż 3 miesiące przerzutami odległymi), przerzutu odległego lub zgonu z innych/nieznanych przyczyn. Dla oceny wpływu czynników prognostycznych na skuteczność leczenia zastosowano model proporcjonalnego ryzyka Coxa [8]. W modelu uwzględniono następujące czynniki prognostyczne: wiek chorych, stan hormonalny, strona leczonej piersi, pT, pN, typ histopatologiczny raka, stopień złośliwości histologicznej (G), obecność komponentu DCIC w raku inwazyjnym, rozmiar marginesów wokół usuniętego guza i podtyp biologiczny raka piersi. Model dopasowano metodą krokowej eliminacji zmiennych dla warunków włączenia i wyłączenia odpowiednio: 0,05 i 0,1. Do porównania rozkładu klasycznych czynników rokowniczych w stosunku do podtypów biologicznych zastosowano test niezależności Chi-2. Do oceny ryzyka nawrotu lokoregionalnego wykorzystano metodę konkurujących ryzyk, przyjmując przerzuty odległe i zgony z innych niż nowotworowe przyczyn lub nieznanych przyczyn jako wydarzenia konkurujące $[9,10]$. Jako estymator ryzyka niepowodzeń użyto funkcję CIF (Cumulative Incidence Function). Za statystycznie istotne przyjęto wartości krytyczne testu mniejsze niż 0,05. Analizę statystyczną przeprowadzono, posługując się pakietem statystycznym IBM SPSS wersja 20 dla systemu operacyjnego Linux.

\section{Wyniki}

Prawdopodobieństwo 5- i 8-letniego przeżycia bezobjawowego z 95-procentowym przedziałem ufności wyniosło odpowiednio: $94 \%(92 ; 96)$ i $89 \%(86 ; 92)$. Nie stwierdzono wzajemnej, statystycznie istotnej różnicy w prawdopodobieństwie przeżycia bezobjawowego dla podtypów biologicznych ani w analizie jednoczynnikowej, ani wieloczynnikowej $(p>0,1)$. Jedynie w analizie jednoczynnikowej wykazano występowanie ujemnego trendu prawdopodobieństwa przeżycia bez niepowodzenia dla podtypów biologicznych w następującym porządku: luminalny HER2 (ujemny), luminalny HER2 (dodatni), trójujemny i nieluminalny HER2 (dodatni) - $p=0,03$ - rycina 1 . Stwierdzono negatywny wpływ na ryzyko niepowodzenia leczenia chorych na raka piersi dla innych, następujących czynników: młody wiek chorych $(p=0,034)$, liczba zajętych przez przerzuty węzłów chłonnych powyżej trzech $(p=0,018)$ i stopień zróżnicowania raka $G(p=0,043)$. Chore poniżej 35 roku życia miały 2,5 razy wyższe ryzyko nawrotu niż chore powy- 


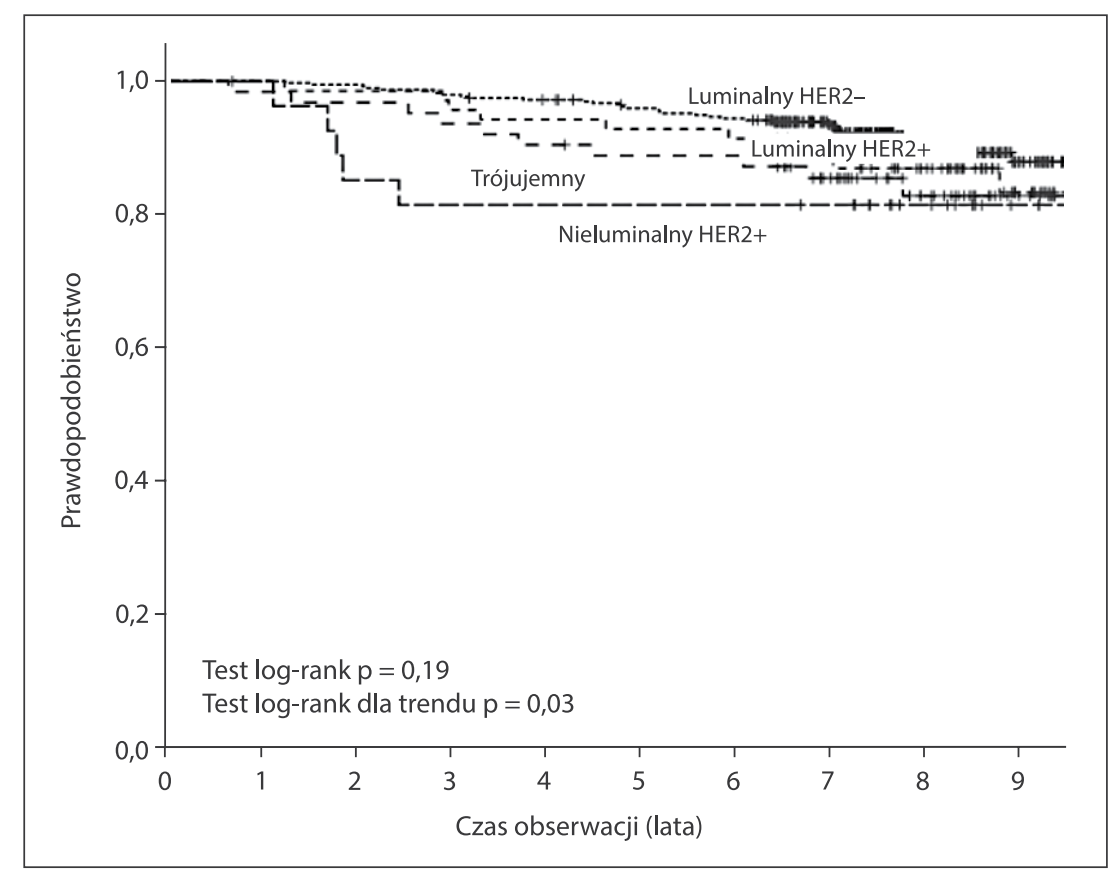

Rycina 1. Przeżycie bezobjawowe 615 chorych na wczesnego raka piersi po leczeniu oszczędzającym (BCT) w zależności od podtypu biologicznego raka piersi - analiza jednoczynnikowa

żej 50 roku życia. Nie stwierdzono statystycznie istotnych różnic dla ryzyka niepowodzenia w grupie chorych z pN0 vs pN1-3 ( $p=0,485)$, natomiast chore, u których liczba zajętych przez przerzuty węzłów chłonnych przekraczała 3, miały 2,6 razy wyższe ryzyko niepowodzenia niż chore z cechą pN0. Stwierdzono, że chore z nisko zróżnicowanym rakiem G3 miały 3 razy wyższe ryzyko niepowodzenia w porównaniu z chorymi na raka typu G1 — tabela III.

Analiza rozkładu badanych czynników prognostycznych potwierdziła, że u chorych w podtypie biologicznym trójujemnym i nieluminalnym HER 2 (dodatnim) znamiennie częściej niż w typach luminalnym HER2 (ujemnym) i luminalnym HER2 (dodatnim) stwierdza się młodsze chore, z większym guzem - pT2, większą liczbą węzłów chłonnych z przerzutami w jamie pachowej pN > 3 i z częściej rozpoznawanym rakiem niskozróżnicowanym G3 — tabela IV. Skumulowany odsetek 5-i 8-letnich niepowodzeń wraz z 95-procentowym przedziałem ufności wyniósł odpowiednio: 0,024 (-0,043; $0,092)$ i $0,046(-0,072 ; 0,164)$ dla nawrotów lokoregionalnych,
Tabela III. Czynniki prognostyczne dla przeżycia bezobjawowego - model proporcjonalnego ryzyka Coxa

\begin{tabular}{lcc}
\hline Czynnik prognostyczny & $\begin{array}{c}\text { Wartość } \\
\mathbf{p}\end{array}$ & $\begin{array}{c}\text { Ryzyko względne } \\
(95 \% \text { PU*) }\end{array}$ \\
\hline Wiek & & \\
Grupa referencyjna $>50$ & 0,034 & \\
$\quad 35-50$ & 0,033 & $1,8(1,05 ; 2,97)$ \\
$\quad<35$ & 0,044 & $2,5(1,03 ; 6,11)$ \\
Liczba w/ch pN (+) & & \\
Grupa referencyjna pN0 & 0,06 & \\
$\quad 1-3$ & 0,485 & $1,2(0,7 ; 2,3)$ \\
$\quad>3$ & 0,018 & $2,6(1,2 ; 5,7)$ \\
G & & \\
Grupa referencyjna G1 & 0,043 & \\
$\quad$ G2 & 0,027 & $2,6(1,11 ; 5,89)$ \\
G3 & 0,016 & $3,0(1,22 ; 7,24)$ \\
$\quad$ Gx & 0,4 & $1,5(0,59 ; 3,79)$ \\
\hline
\end{tabular}

PU — przedział ufności

Tabela IV. Rozkład czynników prognostycznych w zależności od podtypu biologicznego

\begin{tabular}{lccccc}
\hline Czynnik & \multicolumn{5}{c}{ Podtyp biologiczny raka piersi } \\
\cline { 2 - 6 } & $\begin{array}{c}\text { Luminalny HER2(-) } \\
\%\end{array}$ & $\begin{array}{c}\text { Luminalny HER2(+) } \\
\%\end{array}$ & $\begin{array}{c}\text { Trójujemny } \\
\%\end{array}$ & $\begin{array}{c}\text { Nieluminalny HER2(+) } \\
\%\end{array}$ & $\begin{array}{c}\chi^{2} \\
\text { p }\end{array}$ \\
\hline PT2 & 17 & 24 & 41 & 37 & 0,000 \\
PN $>3$ & 4,3 & 4,3 & 8 & 15 & 0,002 \\
G3 & 9,5 & 14,3 & 58,7 & 44,4 & 0,000 \\
Wiek - mediana & 53,9 & 52,6 & 50,2 & 50,2 & 0,000 \\
\hline
\end{tabular}




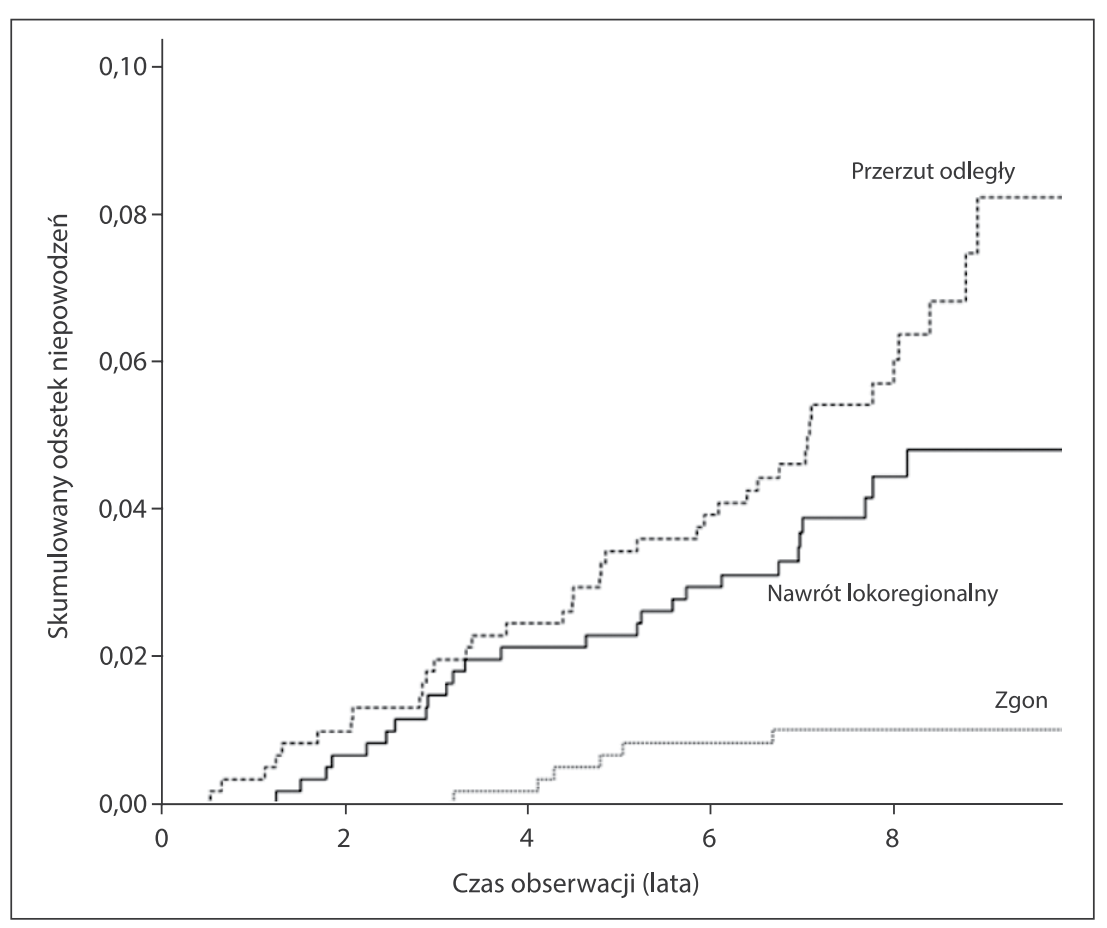

Rycina 2. Skumulowany odsetek niepowodzeń wśród 615 chorych na wczesnego raka piersi po leczeniu oszczędzającym (BCT)

$0,034(0,028 ; 0,041)$ i $0,06(0,041 ; 0,080)$ dla przerzutów odległych oraz $0,003(0,003 ; 0,003)$ i $0,01(0,01 ; 0,01)$ dla zgonów z przyczyn nienowotworowych lub nieznanych — rycina 2.

\section{Dyskusja}

Prezentowany w pracy materiał obejmuje chore na wczesnego raka piersi leczone metodą oszczędzającą, w jednym ośrodku, przez ten sam zespół lekarzy, w oparciu o własny protokół i ówczesne zalecenia międzynarodowe [4]. W latach 2003-2006 w Centrum Onkologii stosowano rutynowo w procedurze chirurgicznej leczenia oszczędzającego biopsję węzła wartowniczego, która w znacznej mierze zmniejsza ryzyko obrzęku kończyny górnej do 3\% z 30\% po limfadenektomii pachowej [11]. W analizowanej grupie u prawie połowy chorych (49\%), diagnostykę węzłów pachowych zakończono na biopsji węzła wartowniczego, a u 51\% wykonano limfadenektomię z powodu dodatniego węzła wartowniczego lub wysoko, blisko pachy zlokalizowanej zmiany pierwotnej. W leczeniu pooperacyjnym stosowano programy chemioterapii zawierające cytostatyki 2 i 3 generacji. W badaniach immunohistochemicznych tkanki nowotworowej oznaczano receptory steroidowe i HER2, uzupełniając w niektórych przypadkach badanie HER2 na dwa plusy o ocenę statusu HER2 badaniem FISH (fluorescence in situ hybridization ). Nie oznaczano natomiast markera proliferacji Ki 67. Nie stosowano również rutynowo leczenia celowanego molekularnie, nakierowanego na receptor HER2. Wszystkie chore po operacji napromieniane były metodą łagodnej hipofrakcjonacji dawki, z bardzo do- brą tolerancją i efektem kosmetycznym porównywalnym do uzyskiwanego po klasycznej 5-tygodniowej radioterapii.

Odsetek podtypów biologicznych w naszym materiale był podobny jak prezentowanych $w$ innych publikacjach $[12,13]$. Nguyen i wsp. z Dana-Farber Cancer Institute ocenili 5-letnie skumulowane ryzyko nawrotu lokoregionalnego i przerzutów u podobnie leczonej bez trastuzumabu grupy 793 chorych na wczesnego raka piersi na 1,8\% i 6,3\% [12]. W naszym materiale osiągnęliśmy porównywalne rezultaty po 5 i 8 latach: odpowiednio 2,4\% i 4,6\%, 3,4\% i 6\%. Tak dobre wyniki leczenia można było osiągnąć dzięki temu, że u każdej chorej zespołowo na podstawie danych klinicznych i badania mikroskopowego dobierany był schemat leczenia uzupełniającego. Tylko takie postępowanie może zapewnić optymalne wyniki leczenia.

Grupa badaczy kanadyjskich z British Columbia Cancer Agency dokonała przeglądu i oceny nawrotów raka piersi przed erą wprowadzenia do leczenia uzupełniającego przeciwciała monoklonalnego anty-HER2 oraz inhibitorów aromatazy i po wprowadzeniu tego leczenia w zależności od podtypów biologicznych raka piersi, których surogatem był układ receptorów steroidowych i HER2. W tym celu porównano dwie grupy chorych na raka piersi w stopniach I-III leczonych w latach 1986-1992 (3589 chorych) i 2004-2008 (3589 chorych). U chorych z drugiej grupy, które podzielono na 4 podtypy biologiczne (luminalny HER2 dodatni, luminalny HER2 ujemny, nieluminalny HER2 dodatni i trójujemny) i wobec których stosowano uzupełniające leczenie antracyklinami, taxanami, trastuzumabem i inhi- 
bitorami aromatazy, ryzyko nawrotu dla porównywalnych chorych było o około połowę mniejsze niż w grupie pierwszej, leczonej uzupełniająco zgodnie z programem CMF i tamoksifenem. Stwierdzono jednakże, że o ile w związku z bardziej agresywnym i celowanym leczeniem chorych w grupie drugiej ryzyko nawrotów było mniejsze we wszystkich podtypach biologicznych raka piersi, to relacje między krzywymi nawrotów dla badanych grup chorych były podobne w obu grupach [13].

W naszym materiale pomimo braku w analizie jednoczynnikowej istotności statystycznej pomiędzy krzywymi przeżycia bezobjawowego dla podtypów biologicznych raka piersi (zwykły test log-rank $p=0,19$ ), to test log-rank na trend $p=0,03$ potwierdził, że ryzyko nawrotów rosło $w$ kolejności: typ luminalny HER2 ujemny, luminalny HER2 dodatni, trójujemny i nieluminalny HER2 dodatni. W pracy potwierdzono fakt prezentowany przez wielu autorów, że z podtypami HER2 dodatnim i trójujemnym związane są znamiennie częściej niż podtypach luminalnych niekorzystne czynniki prognostyczne takie jak: młody wiek chorych, większe zaawansowanie pT i pN choroby nowotworowej i niskie zróżnicowanie raka G3 [12, 13]. W analizie wieloczynnikowej stwierdzono jednak, że jeśli do modelu włączono niekorzystne czynniki prognostyczne i oddzielnie podtypy biologiczne, to okazało się, że podtypy biologiczne per se wypadły z modelu jako nieistotne, natomiast istotne okazały się: młody wiek chorych, liczba zajętych przez przerzuty węzłów chłonnych powyżej 3 i G3. W licznych obecnie publikacjach uważa się, że rak piersi receptorowo ujemny należy do bardzo heterogennej genetycznie grupy, z której część odpowiada na standardowe leczenie, a część nie i wymaga dalszej diagnostyki molekularnej i nowych niestandardowych leków [14-16].

\section{Wnioski}

1. Wysokie prawdopodobieństwo 8-letniego przeżycia bezobjawowego chorych i niskie ryzyko nawrotu lokoregionalnego raka piersi upoważnia do pozytywnej oceny leczenia oszczędzającego w Centrum Onkologii w latach 2003-2006.

2. Pomimo agresywnego leczenia nadal najsilniejszymi czynnikami prognostycznymi pozostają: młody wiek chorych, liczba zajętych przez przerzuty węzłów chłonnych w pasze powyżej trzech i niskie zróżnicowanie raka G3.

3. Gorsze rokowanie chorych z rozpoznanym podtypem raka piersi nieluminalnym HER2 (dodatnim) uzasadnia wprowadzenie leczenia celowanego molekularnie, nakierowanego na receptor HER2.

\section{Konflikt interesów: nie zgłoszono}

\author{
Dr n. med. Jacek Gałecki \\ Zakład Teleradioterapii \\ Centrum Onkologii - Instytut \\ im. Marii Skłodowskiej-Curie \\ ul. Roentgena 5, 02-781 Warszawa \\ e-mail:jacekgg@poczta.fm
}

Otrzymano: 20 maja $2015 \mathrm{r}$.

Przyjęto do druku: 13 października 2015 r.

\section{Piśmiennictwo}

1. Pieńkowski T. Czynniki predykcyjne u chorych na raka sutka. Nowotwory 2000; 50: 165-170.

2. Bręborowicz E. Wybrane czynniki prognostyczne ipredykcyjne u młodych kobiet chorych na raka piersi. Poznań 2011, praca doktorska dostępna 23.08.2015 na: http://www.wbc.poznan.pl/dlibra/docmetadata?i$\mathrm{d}=185244 \&$ from $=\&$ dirids $=1 \&$ ver $i d=\&|\mathrm{p}=1 \& \mathrm{Q}|=$ F87BA481BAEB16DEF5AA4AA6EB069DCA-2.

3. Soerjomataram I, Louwman MW, Ribot JG i wsp. An overview of prognostic factors for long-term survivors of breast cancer. Breast Cancer Res Treat 2008; 107: 309-330.

4. Goldhirsch A, Glick JH, Gelber RD i wsp. Meeting highlights: international expert consensus on the primary therapy of early breast cancer 2005. Ann Oncol 2005; 16: 1569-1583.

5. Coates AS,Winer EP, Goldhirsch A i wsp. Tailoring therapies-improving the management of early breast cancer: St. Gallen International Expert Consensus on the Primary Therapy of Early Breast Cancer 2015. Ann Oncol 2015; 26: 1533-1546.

6. ICRU (International Commision on Radiation United and Measurments) Prescribing, recording and reporting photon beam therapy. ICRU Report 50. Bethesda, 1993

7. Kaplan FL, Meier P. Nonparametric estimation from incomplete observations. J Am Stat Assoc 1958; 52: 457-481.

8. Cox DR. Regression models and life tables.JRStat Soc B 1972; 34: 187-220.

9. Arriagada R, Rutqvist LE, Kramar A i wsp. Competing risks determining event-free survival in early breast cancer. Br J Cancer 1992; 66: 951-957.

10. Karlsson P, Cole BF, Price KN i wsp. The role of the number of uninvolved lymph nodes in predicting locoregional recurrence in breast cancer. J Clin Oncol 2007; 25: 2019-2026.

11. American Cancer Society. Breast cancer. Dostępna 23.08.2015 na: http://www.cancer.org/cancer/breastcancer/detailedguide/breast-cancer-treating-surgery.

12. Nguyen PL, Taghian AG, Katz MS i wsp. Breast cancer subtype approximated by estrogen receptor, progesterone receptor, and HER-2 is associated with local and distant recurrence after breast-conserving therapy. J Clin Oncol 2008; 26: 2373-2378.

13. Cossetti RJ, Tyldesley SK, Speers CH i wsp. Comparison of breast cancer recurrence and outcome patterns between patients treated from 1986 to 1992 and from 2004 to 2008. J Clin Oncol 2015; 33: 65-73.

14. van de Vijver MJ, He YD, van 't Veer LJ i wsp. A gene-expression signature as a predictor of survival in breast cancer. N Engl J Med 2002; 347: 1999-2009.

15. Engstrøm MJ, Opdahl S, Hagen Al i wsp. Molecular subtypes, histopathological grade and survival in a historic cohort of breast cancer patients. Breast Cancer Res Treat 2013; 140: 463-473.

16. Couch FJ, Hart SN, Sharma P i wsp. Inherited mutations in 17 breast cancer susceptibility genes among a large triple-negative breast cancer cohort unselected for family history of breast cancer J Clin Oncol 2015; 33: 304-311. 